ВПЛИВ ЗАСОБІВ МАСОВОЇ ІНФОРМАЦІї НА ФОРМУВАННЯ ІМІДЖУ ДЕРЖАВНОГО СЛУЖБОВЦЯ

\title{
THE IMPACT OF MASS MEDIA ON THE FORMATION OF CIVIL SERVANTS 'IMAGE
}

У статті розглянута вплив засобів масової інформації на фрормування іміджу державного службовия. Виділено два способи фрормування іміджу: природний і штучний. Встановлено, що точки зору державної влади, імідж -є самопрезентацією, конструюванням державним службовцем обраного ним способу з урахуванням цільової аудиторії в особі тих чи інших суспільних груп.

Фактори форммування іміджу державного службовия поділено на внутрішні та зовнішні. До внутрішніх фракторів належать психологічний стан людини, здоров'я, тип особистості, темперамент, риси характеру, індивідуальний стиль прийняття рішень. Зовнішніми оракторами є: спосіб життя, сімейний стан, культура, освіта, зовнішній вигляд, організаційна культура, ставлення засобів масової інфоормації до службовця, ставлення населення до службовия, його оточення. Прочес орормування іміджу державних службовців є багатофракторною взаємодією змішаного типу трьох суб'єктів: безпосередньо органу влади, населення та засобів масової інформації. Інфрормація, що транслюється в засобах масової інформації про того чи іншого державного службовця може бути прямою або непря мою; при цьому смисловий зміст здатен істотно вплинути на розглянутий імідж. Доведено, що імідж державного службовия - $є$ частиною іміджу держави. Про виконану роботу державних службовців і всіх керівників державних органів влади можна оцінити всю дієвість влади, і їі вміння відгукуватися на потреби людей. Крім профессіналізму державний службовець повинен мати високі моральні якості, в умовах свободи засобів масової інформації та нових інформаційних технологій. В першу чергу, треба піднімати престиж державної служби, для підвищення усвідомлення міри відповідальності перед усім народом.

Встановлено, що для створення іміджу державного службовия саме як образу, який створюється в прочесі впливу на аудиторію, а також сприйняття аудиторією даного впливу, можуть вплинути тільки дві групи фрактів, одна з них залежить від самого службовця, друга - пов'язана з соціально-економічною ситуацією в регіоні та країні. Будь-яка державна служба зобов'язана регулювати суспільні прочеси, а також забезпечувати реалізацію інтересів кожного громадянина і цілісність держави. Також постійно державний сектор знаходиться в центрі життя і в центрі уваги суспільства. Ключові слова: засоби масової інорормаціі, державний службовець, органи державної влади, імідж, громадськість, політика, держава.

The article deals with the influence of the media on the image of a public servant. There are two ways of forming an image: natural and artificial. It is established that the point of view of the state power, the image - is a self-presentation, construction by a public servant of his chosen method, taking into account the target audience in the person of certain social groups.

The factors of forming the image of a civil servant are divided into internal and external. Internal factors include a person's psychological state, health, personality type, temperament, character traits, individual decision-making style. External factors are: lifestyle, marital status, culture, education, appearance, organizational culture, media attitude to the employee, attitude of the population to the employee, his environment The process of forming the image of civil servants is a multifactorial interaction of a mixed type of three entities: directly to the authorities, the population and the media. Information broadcast in the media about a civil servant may be direct or indirect; the semantic content can significantly influence the image.

It is proved that the image of a public servant is part of the image of the state. The work done by civil servants and all heads of state authorities can be evaluated with regard to the entire effectiveness of the government and its ability to respond to people's needs. In addition to professionalism, a civil servant must have high moral qualities, in the conditions of freedom of mass media and new information technologies. First of all, it is necessary to raise the prestige of the civil service in order to raise awareness of the responsibility to the whole people.

It is established that only two sets of facts can affect the image of a public servant as an image created in the process of influencing the audience, as well as the perception of the audience, one of them depends on the employee himself, the other - related to social- economic situation in the region and country. Any public service is obliged to regulate public processes, as well as to ensure the realization of the interests of every citizen and the integrity of the state. Also, the public sector is constantly in the center of life and the focus of society.

Key words: mass media, public authorities, image, public, politics, state.
Постановка проблеми. Органи державної влади в особі окремих її службовців постійно знаходиться в центрі пильної уваги суспільства. Для проведення в будь-якій державі політики, націленої на розвиток і економічне зростання, досить важливим є, наскільки та чи інша влада визнана суспільством, наскільки вона та її дії узгоджені народом, оскільки від цього в повній мірі залежить, якою мірою громадськість готова йти за своєю владою в особі того чи іншого політичного лідера, державного службовця, слідувати курсом розвитку, пропонованим ним.

У питанні досягнення високого рівня довіри не останню роль відіграє персональний імідж того чи іншого службовця, який представляє 
собою набір деяких аспектів, за якими громадськість ідентифікує образ і індивідуальність певного суб'єкта. Оскільки в сучасному суспільстві присутні різні соціальні групи, легітимність влади в державі не може носити загальний характер, тому як, вони (тобто різні соціальні групи) можуть ставитися до політики влади як позитивно, так і негативно.

У зв'язку з цим сьогодні зростає інтерес до проблеми формування позитивного іміджу державного службовця, як одного з вельми важливих як в контексті реформування і трансформації державної служби, взаємодії її з громадянським суспільством, так і в досягненні успішності того чи іншого службовця. Оскільки імідж виступає у ролі певної цінності, від наявності та якості якої в повній мірі залежить життєвий успіх в цілому, так і успішність будь-якої сфери діяльності.

При цьому, сучасні реалії такі, що в процесі формування іміджу державного службовця одне з пріоритетних місць вимагає серйозної і чітко продуманої роботі із засобами масової інформації, здатних сформувати як позитивний, так і негативний імідж.

Саме тому розгляд питання впливу який мають ЗМІ у формуванні позитивного іміджу (образу) державного службовця займає сьогодні високий ступінь актуальності.

Аналіз останніх досліджень і публікацій. Аналіз сучасних публікацій свідчить про те, що особливості формування іміджу органів державної влади розглядають такі вчені, як Ю. Битяк, В. Дрешпак, С. Дубенко, Т. Гаман, Т. Желюк, Д. Кіслов, С. Колосок, Н. Ларіна, М. Логунова, В. Лола, О. Луцький, Ю. Падафет, О. Панасюк, І. Пантелейчук, Г. Почепцов, Є. Ромат, С. Серьогін, Л. Усаченко, Т. Федорів, І. Хожило, В. Чепель та ін. Однак питанню впливу засобів масової інформації формування іміджу державних службовців приділено недостатньо уваги.

Мета статті - проаналізувати вплив засобів масової інформації на формування іміджу державного службовця в Україні.

Виклад основного матеріалу. Процес формування іміджу державних службовців $€$ багатофакторною взаємодією змішаного типу трьох суб'єктів: безпосередньо органу влади, населення та засобів масової інформації. Усі зазначені суб'єкти взаємопов'язані і взаємодіють один з одним у вигляді безпосередньої взаємодії, інформаційного обміну та емоційно-оцінних реакцій.

Виділяють два способи формування іміджу: природний і штучний. При взаємодії службовця з населенням, представниками громадськості, колегами по роботі імідж складається природним шляхом. Однак, якщо розглядати PR-компанію, цілеспрямовану роботу засобів масової інформації, то це штучно створений імідж, який не завжди відображає реальний образ державного службовця, особистісні якості і здібності необхідні для професійної діяльності.

Фактори формування іміджу державного службовця поділяються на внутрішні та зовнішні. До внутрішніх факторів належать психологічний стан людини, здоров'я, тип особистості, темперамент, риси характеру, індивідуальний стиль прийняття рішень. Зовнішніми факторами є: спосіб життя, сімейний стан, культура, освіта, зовнішній вигляд, організаційна культура, ставлення засобів масової інформації до службовця, ставлення населення до службовця, його оточення.

У сучасному суспільстві, часто, населення формує думку про державного службовця за образом, який пропонується в засобах масової інформації. Відповідно засоби масової інформації відіграють у формуванні іміджу значну роль, оскільки можуть інформувати населення про діяльність, імідж державного службовця і цілеспрямовано створювати імідж, який буде виправдовувати очікування населення [1, с.18].

Імідж державного службовця також залежить від громадської думки, яка складається після взаємодії з населенням, звернень громадян до приймальні державного службовця. Позитивний імідж державних службовців залежить від уміння службовця розподілити обов'язки по роботі зі зверненням громадян, визначити час і місце прийому громадян, створити естетичну привабливість зовнішнього вигляду і поведінки, вміння володіти собою і своїми почуттями, вміння вселяти довіру і симпатію, володіння культурою телефонних переговорів, інтерв'ю тощо.

Не менш важливим фактором для створення позитивного іміджу службовця $є$ оточення. Якщо поруч з державним службовцем будуть перебувати гідні, особистості, яких підтримує суспільство, то позитивне ставлення населення до них буде переноситися і на самого службовця.

Робота над іміджем державного службовця повинна здійснюватися безперервно, сприяючи професійному розвитку і просуванню по кар'єрних сходах. Вчені розглядають професійний розвиток службовців в єдності 3 компетентнісним розвитком і визначають як напрям діяльності з управління кадрами, яке спрямоване на забезпечення сталого розвитку професійних компетенцій, що сприяють ефективному виконанню посадових обов'яз- 
ків державних службовців в єдності цілей і завдань державної політики та особистісних установок службовця [2]. Зниження кількості негативних оцінок населення про роботу державних органів і недобросовісного виконання державними службовцями своїх функцій відбувається в процесі вдосконалення позитивного іміджу службовців шляхом розвитку вміння організовувати, регулювати і контролювати свою життєдіяльність, професійну діяльність і поведінку.

З точки зору психології особистості імідж $є$ суб'єктивним образом сприймаються оточуючими, що визначає форму і зміст основних характеристик особистості.

З точки зору PR і реклами, імідж виступає як образ, який є особливим засобом спілкування службовця з певною цільовою аудиторією. Такий образ завжди будується виходячи з існуючих інтересів відповідної цільової аудиторії, при цьому, він повинен легко укладатися в свідомість аудиторії і мати здатність відтворюватися при зверненні до неї.

3 точки зору державної влади, імідж фактично $€$ самопрезентацією, конструюванням державним службовцем обраного ним способу з урахуванням цільової аудиторії в особі тих чи інших суспільних груп.

При існуючому сьогодні в науці різноманітті підходів до визначення поняття «імідж» практично всі дослідники згодні з тим, що сьогодні імідж - це, в першу чергу, модельований образ, свідомо створюваний і надалі трансльований тій чи іншій цільовій аудиторії. При цьому його формування базується на основі реальної поведінки того чи іншого індивіда, під впливом оцінок і думок про нього [3, с.25].

Важливо розуміти, що імідж - це категорія не статична, його неможливо раз придбати і володіти ним завжди. Тому він вимагає цілеспрямованого управління: створення, розвитку (підтримки) і систематичного поширення (трансляції) [4, с.409].

На кожному з етапів управління іміджем вагоме місце відводиться ЗМІ, особливо в тому випадку, коли у державного службовця відсутня можливість безпосереднього особистого контакту з суспільством. При цьому, якщо на якомусь із зазначених етапів не надати управлінського впливу на імідж, він може бути в різних ЗMI представлений як негативний. Для управління позитивним іміджем (образом) державного службовця необхідно знати основні фактори, здатні надати максимальний вплив на сприйняття його цільовою аудиторією.

Перше, що впливає на формування позитивного іміджу - це безпосередньо сама особистість і її основні якості. Так, особистість людини формує його внутрішні і зовнішні якісні характеристики.

До внутрішніх відносять безпосередньо психологічні властивості і внутрішній світ індивіда, до зовнішніх - його поведінкові особливості в соціумі, які, в свою чергу, формуються на підставі розвитку внутрішніх якостей.

I ті, і інші можуть бути передані широкому колу громадськості, за допомогою різних засобів масової інформації; вони можуть виражатися з різним емоційним забарвленням, що і сформує, в свою чергу, той чи інший, позитивний або негативний імідж (образ) державного службовця.

При цьому про негативні зміни в самій особистості інформація в ЗМІ блискавично поширюється широкому колу громадськості, завдаючи серйозного удару по іміджу і репутації державного службовця, порушуючи ступінь довіри до нього. Здійснюючи той чи інший вчинок (як свідому дію), за допомогою реалізації якого державний службовець затверджується як особистість, або проступок (як дія або бездіяльність, яка посягає на суспільні відносини), держслужбовець повинен розуміти, що реакція з боку ЗМІ буде практично миттєвою. Тобто для створення позитивного іміджу йому необхідно чітко зважувати кожну свою дію, намагаючись уникати вчинення проступків [5, с.241].

Інформація, що транслюється в ЗМІ про того чиіншогодержавногослужбовцяможебутипрямою або непрямою; при цьому смисловийзміст здатен істотно вплинути на розглянутий імідж.

Так, за допомогою інтерв'ю в ЗМІ той службовець, який має на це встановлене законом право, може цілеспрямовано передати аудиторії ту чи іншу інформацію про себе. Видана, наприклад, в жовтій пресі інформація у вигляді чуток, домислів і припущень, тобто нічим не підтверджені повідомлення, зараховують до непрямої інформації, здатні надати дуже негативний вплив на імідж [6, с.138]

Улюбленою темою у різних засобах масової інформації, крім зазначеного інтерв'ювання, $\epsilon$ розгляд досвіду того чи іншого службовця в розрізі його безпосередньої професійної діяльності, реалізація в рамках якої тих чи інших проектів, здатні значно поліпшити імідж, додавши йому позитивних характеристик.

3 огляду на сучасний рівень розвитку мережі інтернет (як одного 3 широко затребуваних сьогодні каналів масової комунікації), багато політичних діячів і державних службовців від власного імені транслюють інформацію про себе за допомогою мережі Інтернет. І це видається найбільш перспективним каналом комунікації в даний час, оскільки характерною рисою сучасного високо інформаційного 
суспільства є інтенсивний розвиток діджіталізаціі [7, с.18].

Цілеспрямоване формування позитивного іміджу (образу) державного службовця досить трудомісткий процес, реалізувати який поодинці сьогодні практично неможливо [7, с.19] Тому багато хто з керівників державної служби мають спеціальний штат іміджмейкерів, PR і GR співробітників, основною метою діяльності яких є створення, розвиток і підтримка на належному рівні позитивного іміджу державного службовця шляхом постійного підігрівання інтересу до нього з боку суспільства через трансляцію інформації в різних засобах масової інформації та мережі Інтернет.

ЗМІ продовжують відігравати вагому роль у створенні і формуванні громадської думки з того чи іншого питання, в тому числі щодо іміджу державного службовця. Засоби масової інформації все ще займають більшу частину дозвілля: люди в середньому 25 годин на тиждень проводять, дивляться телевізор, слухають радіо, читають газети і журнали [8, с.21].

Тривалий і дуже складний процес - це особливе утворення позитивного іміджу державного службовця. Поведінка і робота держслужбовця постійно на виду. Тому його імідж $€$ частиною іміджу даної держави. Також про виконану роботу державних службовців і всіх керівників державних органів влади можна оцінити всю дієвість влади, і її вміння відгукуватися на потреби людей. Звідси велика відповідальність, що лежить на плечах держслужбовців. Крім професіоналізму необхідно мати високі моральні якості, в умовах свободи ЗМІ та нових інформаційних технологій. В першу чергу, треба піднімати престиж державної служби, для підвищення усвідомлення міри відповідальності перед усім народом.

Для створення іміджу державного службовця саме як образу, який створюється в процесі впливу на аудиторію, а також сприйняття аудиторією даного впливу, можуть вплинути тільки дві групи фактів, одна з них залежить від самого службовця, друга - пов'язана з соціально-економічною ситуацією в регіоні та країні. Будь-яка державна служба зобов'язана регулювати суспільні процеси, а також забезпечувати реалізацію інтересів кожного грома- дянина і цілісність держави. Також постійно державний сектор знаходиться в центрі життя і в центрі уваги суспільства.

Висновки. Проаналізувавши сучасні аспекти іміджу державного службовця, різні фактори, що впливають на нього в їх взаємозв'язку зі ЗМІ, стало ясно, яку важливу роль вони відіграють на сучасному етапі в поширенні іміджформучої інформації.

Сьогодні особливо актуально управляти іміджем, використовуючи найсучасніші, найбільш затребувані, а тому високопродуктивні канали зв'язків з громадськістю, як соціальні мережі, за фаховою допомогою професіоналів з PR і фахівців в сфері формування і розвитку іміджу.

Поряд 3 особистими, професійними якостями державного службовця це дозволить під впливом ЗМІ сформувати позитивний імідж не тільки кожного окремого державного службовця, а й України як держави в цілому.

\section{ЛITЕРАТУРА:}

1. Дубас О. Інфрормаційний розвиток сучасної України у світовому контексті. К.: Генеза, 2004. 207 с.

2. Поліщук О. В. Імідж держави на міжнародній арені: інфрормаційний аспект. URL: http://naub.org.ua/ ? $\mathrm{p}=1204$.

3. Пантелейчук І.В.Формування позитивного іміджу органів державної влади: теорія, методологія, практика: монографрія / І.В.Пантелейчук. К.: Альтерпрес, 2011. 316 с.

4. Гаман Т.В., Андрійчук О.А. Роль і значення зв'язків 3 громадськістю у фрормуванні позитивного іміджу органів державної влади: Університетські наукові записки. 2011. № 4 (40). С. 408-415.

5. Западинчук О.П. Формування іміджу державної служби в умовах розвитку інорормаційного суспільства: Державне управління та місцеве самоврядування. 2012. № 3 (14). С. 239-247.

6. Сімеоніді І. А. Формування іміджу державної служби: Актуальні проблеми державного управління, педагогіки та психології: зб. наук. пр. - Херсон, 2010. № 1-2. С. 136-146.

7. Формування позитивного іміджу органів влади через підвищення якості надання адміністративних та соціальних послуг: наук. розробка / Авт. кол.: С.М. Серьогін, В.В. Лола, І. І. Хожило та ін.; за заг. ред. С.М. Серьогіна. К.: НАДУ, 2009. 32 с.

8. Ларіна Н. Імідж як комунікативна основа позиціонування влади: Вісник державної служби України. 2013. № 2. С. 20-23. 